\title{
HUBUNGAN DUKUNGAN KELUARGA TERHADAP KEPATUHAN MINUM OBAT PADA PENDERITA TUBERKULOSIS
}

\author{
Relationship Of Family Support To Drug Compliance In Tuberculosis Patients
}

\author{
Muhamad Rizal \\ Mantovani ${ }^{\text {** }}$ \\ Firtiani Ningsih ${ }^{2}$ \\ Lensi Natalia Tambunan \\ 3
}

*STIKes Eka Harap Palangka Raya,Palangka Raya,Kalimantan Tengah,Indonesia

*email:

Abahrizall000@gmail.co.id

Kata Kunci:

Dukungan Keluarga

kepatuhan Minum obat

penderita tuberculosis

Keywords:

family support

adherence to medication

tuberculosis patients

\begin{abstract}
Abstrak
Latar Belakang : Tuberkulosis (TBC) yang juga sering disebut "flek paru" adalah gangguan pernapasan kronis yang disebabkan oleh infeksi bakteri Mycobacterium Tuberculosis. Fenomena yang di didapatkan masih ada penderita tuberkulosis yang tidak patuh dalam mengkonsumsi obat OAT. penderita yang tidak patuh Disebabkan oleh kurangnya dukungan keluarga kepada penderita tuberculosis dan berpotensi risiko resisten terhadap obat tuberkulosis pada penderita tuberkulosis

Tujuan Penelitian : Penelitian ini bertujuan untuk mengetahui Hubungan Dukungan Keluarga Dengan Kepatuhan Minum Obat Pada Pasien Tuberculosis berdasarkan data melalui metode literature review.

Metode Penelitian : Menggunakan metode literature review. Penelusuran jurnal menggunakan database akademik yaitu Google Scholar yang publikasi pada tahun 2017-2020 menggunakan Bahasa Indonesia dan Bahasa Inggris. Desain penelitian Cross-sectional.

Hasil : Diperoleh 6 hasil penelitian sesuai kriteria inklusi. Sampel penelitian ratarata 26-83 responden. terdapat 5 jurnal yang menyatakan adanya hubungan antara Dukungan keluarga dan kepatuhan minum obat pada penderita tuberkulosis yang menunjukan nilai $\mathrm{p}$ value $<0,05$, sedangkan I jurnal menyatakan tidak terjadi hubungan antara Dukungan keluarga dengan kepatuhan minum obat pada penderita tuberkulosis diperoleh rvalue $>0,05$

Kesimpulan : Dukungan keluarga yang baik maka mempengaruhi pengobatan teratur pada penderita tuberkulosis yang diharapkan akan membantu keberhasilan penderita tuberkulosis untuk sembuh. Semakin tinggi Dukungan keluarga pada TBC maka semakin baik kepatuhan minum obat TBC dan menunjukan bahwa ada hubungan yang sangat bermakna antara Dukungan keluarga dengan kepatuhan minum obat pada penderita Tuberkulosis

Kata Kunci : Dukungan keluarga,kepatuhan Minum obat,penderita tuberculosis Daftar Pustaka : 29 (20II-2020)
\end{abstract}

\begin{abstract}
Background: Tuberculosis (TBC) which is also often called "pulmonary spots" is a chronic respiratory disorder caused by infection with the bacterium Mycobacterium Tuberculosis. The phenomenon that is obtained is that there are still tuberculosis patients who do not comply with taking OAT drugs. Patients who do not comply are caused by a lack of family support for tuberculosis patients and the potential risk of drug resistance in tuberculosis patients.

Research Objectives: This study aims to determine the relationship between family support and Drug Compliance in Tuberculosis Patients based on data through the literature review method.

Research Methods: Using the literature review method. Journal searches use an academic database, namely Google Scholar, which was published in 2017-2020 using Indonesian and English.study design Cross-sectional.

Results: Obtained 6 research results according to the inclusion criteria. The research sample averaged 26-83 respondents. There are 5 journals which state that there is a relationship between family support and medication adherence in tuberculosis patients which shows a $p$ value $<0.05$, while I journal states that there is no relationship between family support and medication adherence in tuberculosis patients.

Conclusion: Good family support will affect the regular treatment of tuberculosis patients which is expected to help the success of tuberculosis patients to recover. The higher the family support for tuberculosis, the better the adherence to taking TB medication and shows that there is a very significant relationship between family support and medication adherence in patients with tuberculosis
\end{abstract}

Bibliography : 29 (20I I-2020) 


\section{PENDAHULUAN}

Tuberkulosis (TBC) yang juga sering disebut "flek paru" adalah gangguan pernapasan kronis yang disebabkan oleh infeksi bakteri Mycobacterium Tuberculosis. Penyakit TBC merupakan masalah kesehatan masyarakat yang penting di dunia.Menurut laporan $\mathrm{WHO}$, Indonesia berada dalam daftar 30 negara dengan beban tuberkulosis tertinggi di dunia dan menempati peringkat tertinggi ke dua di dunia terkait angka kejadian tuberkulosis. Insidensi tuberkulosis di Indonesia pada tahun 2018 adalah 316 per 100.000 penduduk atau diperkirakan sekitar 845.000 penduduk menderita tuberkulosis pada tahun 2018. WHO menyebutkan, ada sekitar I,7 juta orang yang meninggal akibat TBC di dunia, sedangkan di Indonesia diperkirakan ada 92.700 orang meninggal akibat TBC, setiap detik ada satu orang yang terinfeksi tuberkulosis di dunia. Sepertiga penduduk dunia telah terinfeksi kuman tuberkulosis. Sekitar 45\% dari total kasus penyakit TBC di dunia ditemukan di Asia Tenggara. Penyakit Tuberculosis merupakan penyakit kronis (menahun) yang sukar sembuh dan dapat menular melalui droplet ke udara (Kemenkes RI, 2019). Indonesai menjadi negara dengan beban tinggi bersama 4 negara lain yaitu India, China, Philipina dan, Pakistan untuk kasus Tuberculosis, Tuberculosis dengan HIV, Tuberkulosis dengan Resisten Obat (Kemenkes RI, 2019). Palangka raya menjadi provinsi ke Empat belas terbesar Prevalensi TB Paru Berdasarkan Riwayat Diagnosis Dokter Menurut Kabupaten/ Kota Provinsi Kalimantan Tengah (Kemenkes, 2018). Kalimantan Tengah juga Menempati Urutan Dua puluh Satu dari Tiga puluh Empat provinsi di Indonesia dalam jumlah penemuan penderita penemuan TBC BTA + kasus baru 0,39\% dan 10.189 khasus Kemenkes (2018).Keberhasilan ( succes Rate/SR) pengobatan TB Paru di kota Palangka Raya.Succes rate pada tahun 2018 mencapai $71,43 \%$,mengalami peningkatan dibandingkan tahun
2017 mencapai 29,89\%,tahun 2016 mencapai 33\% dan tahun 2015 mencapai 19,28\%. Angka keberhasilan ( succes Rate/SR) pengobatan TB Paru di kota Palangka Raya tahun 2018 masih di bawah target nasional yaitu $85 \%$. Ada beberapa penyebab yang dimungkinkan, salah satunya adalah terjadinya resistensi obat TB paru pada pasien. Resistensi obat disebabkan beberapa hal antara lain; pasien tidak mematuhi anjuran dokter / petugas kesehatan,tidak teratur menelan OAT susai panduan, penghentikan pengobatan secara sepihak sebelum waktunya, dan gangguan penyerapan obat TB Paru. Dalam Riskesdas Tahun 2018, menggambarkan proporsi pengobatan yang pernah atau sedang diterima oleh responden. Faktor yang mempengaruhi kepatuhan pasien dalam minum obat adalah faktor predisposisi meliputi pengetahuan, kepercayaan, keyakinan, nilai,dan sikap.Sesuai dengan fungsi pemeliharaan kesehatan, keluarga mempunyai 5 tugas di bidang kesehatan, salah satunya yaitu memberikan perawatan kepada keluarga yang sakit.Salah satu faktor yang berpengaruh bagi seseorang ketika menghadapi masalah kesehatan adalah Dukungan keluarga, juga sebagai suatu strategi dalam pencegah dan dukungan keluarga juga memegang peranan penting dalam kehidupan penderita tuberkulosis berjuang untuk sembuh, berpikir ke depan, dan menjadikan hidupnya lebih bermakna Pitters et al (2019). Solusi yang dapat diberikan sebagai tenaga kesehatan masyarakat ialah melakukan Promosi kesehatan kepada penderita Tuberkulosis dan juga kepada keluarga penderita tuberculosis agar penderita faham jika tidak di ikuti sesuai aturan yang berlaku maka pengobatan tuberculosis susah untuk sembuh bahkan menimbulkan resistensi obat /Multi Drug Resistence pada penderita tuberculosis.

Berdasarkan dari uraian di atas maka penulis tertarik meneliti judul hubungan dukungan keluarga terhadap kepatuhan minum obat pada penderita Tuberkolosis. 


\section{METODOLOGI}

Penelitian ini merupakan penelitian Studi literature Review yang dimana bahwa dijelaskan Literature review adalah uraian tentang teori, temuan, dan bahan penelitian lainnya yang diperoleh dari bahan acuan yang akan dijadikan landasan kegiatan penelitian untuk menyusun kerangka pemikiran yang jelas dari perumusan masalah yang ingin diteliti oleh peneliti Notoatmodjo S (2015).

Pada penelitian literature review yanga akan diteliti dengan judul Hubungan Dukungan Keluarga Terhadap kepatuhan Minum Obat Pada Penderita Tuberkulosis.

\section{HASIL DAN PEMBAHASAN}

Hasil dari pencarian Literature telah ditemukan 6 Jurnal yang terkait dengan hubungan Dukungan keluarga terhadap kepatuhan minum obat pada penderita tuberculosis. Dari 6 jurnal tersebut, terdapat 5 jurnal yang menyatakan terdapat hubungan antara Dukungan keluarga dan kepatuhan minum obat pada penderita tuberkulosis, sedangkan I jurnal menyatakan tidak terjadi hubungan antara Dukungan keluarga dengan kepatuhan minum obat pada penderita tuberkulosis.

Hal ini dengan didukungnya penelitian pertama oleh Mongi et al., (20/7) dengan hasil uji statistik dengan menggunakan chi-square diperoleh nilai $\rho$-value $=$ 0,010 lebih kecil dari nilai $\alpha=0,05$.

Penelitian ke dua oleh Netty et al., (20/8) Dengan uji chi square diperoleh nilai $p=0,019<\alpha=0,05$ pada tingkat kepercayaan 95\% menunjukkan bahwa ada hubungan antara dukungan keluarga dengan tingkat kepatuhan minum obat.

Penelitian ketiga Nesi et al., (20/7) Dibuktikan dengan hasil perhitungan menggunakan uji spearmen rho didapatkan nilai $p$ value $(0,000)<0,05$. Hal ini berarti Ho ditolak yaitu ada hubungan dukungan dan pengetahuan keluarga terhadap tingkat kepatuhan berobat penderita tuberculosis.
Penelitian keempat Penelitian Sara \& Suprayitno, (2017) Hasil analisis didapatkan adanya hubungan antara Dukungan keluarga dengan tingkat kepatuhan minum obat pada penderita tuberculosis, dibuktikan dengan hasil Chi-square di peroleh nilai $\mathrm{p}=0,008$ yang berarti $\mathrm{p}<0,05$.

Penelitian kelima Pitters et al., (2019) Berdasarkan hasil uji statistik Rank Spearmen diperoleh nilai $\mathrm{P}<0.05$ yaitu $\mathrm{p}=0.000$ yang berarti dukungan keluarga ada hubungannya dengan kepatuhan minum obat pada pasien TB Paru.

Penelitian keenam Berbading terbalik dengan penelitian Wianti, (20/7) Dibuktikan dengan hasil dari uji statistik diperoleh $\rho$ value $=0,069$ dan $\alpha=0,05(p>\alpha)$, sehingga tidak ada hubungan antara dukungan keluarga dengan kepatuhan minum obat pada pasien Tuberculosis.

\section{KESIMPULAN}

Berdasarkan hasil telaah artikel penelitian yang dilakukan oleh peneliti mengenai Hubungan Dukungan Keluargaa terhadap kepatuhan minum obat pada penderita tuberkulosis maka penulis simpulkan bahwa terdapat:

Berdasarkan hasil telaah dari 6 jurnal dimana hasil sekunder didapatkan lebih dominan responden mendapatkan dukungan keluarga yang baik.Ada 5 jurnal dari 6 jurnal yang di analisis .Jurnal tersebut yaitu dari penelitian Mongi et al., (2017), Netty et al., (20/8), Nesi et al., (2017),Sara \& Suprayitno, (2017),dan Pitters et al., (2019).Sedangkan dukungan keluarga yang masih kurang yaitu dari penelitian Wianti, (2017) yang menyatakan bahwa dari 68 orang responden yang kurang mendapat dukungan keluarga sebanyak 37 orang dan responden yang mendapat dukungan keluarganya baik sebanyak 3I orang. Maka dapat ditarik kesimpulan penderita tuberkulosis adanya dukungan keluarga yang baik maka mempengaruhi pengobatan teratur pada penderita tuberkulosis yang diharapkan akan membantu keberhasilan penderita 
tuberkulosis untuk sembuh,Selain itu dukungan keluarga juga senantiasa untuk dapat mengontrol anggota keluarganya supaya tidak terjadi putus minum obat dan menunjukan bahwa ada hubungan yang sangat bermakna antara Dukungan keluarga dengan kepatuhan mium obat pada penderita Tuberkulosis dan resistensi terhadap obat .Perlu adanya kegiatan penyuluhan kesehatan yang berkaitan dengan informasi mengenai penyakit Tuberkulosis dan informasi mengenai kepatuhan minum obat Tuberkulosis

\section{UCAPAN TERIMA KASIH}

Puji syukur peneliti panjatkan kepada Tuhan Yang Maha Esa, karena atas berkat dan rahmat-Nya, peneliti dapat menyelesaikan penyusunan Skripsi ini. Penulisan Skripsi ini dilakukan dalam rangka memenuhi salah satu syarat untuk mencapai gelar Sarjana Kesehatan Masyarakat pada Sekolah Tinggi Ilmu Kesehatan Palangka Raya. Peneliti menyadari bahwa, tanpa bantuan dan bimbingan dari berbagai pihak pada penyusunan Skripsi ini, sangatlah sulit bagi peneliti untuk menyelesaikan laporan ini. Oleh karena itu peneliti mengucapkan terima kasih kepada:

I) Maria Adelheid Ensia, S.Pd., M.Kes selaku ketua STIKes Eka Harap Palangka Raya

2) Lensi Natalia Tambunan, SST., M.Kes selaku ketua Prodi SI Kesehatan Masyarakat dan selaku pembimbing II

3) Fitriani Ningsih, SST., M.Kes selaku pembimbing I yang telah menyediakan waktu, tenaga dan pikiran untuk mengarahkan penulis dalam penyusunan Proposal ini

4) Rizki Muji Lestari, SST., M. Kes selaku penguji yang telah menyediakan waktu, tenaga dan pikiran untuk menguji penulis

5) Orang tua dan keluarga yang senantiasa mendoakan saya
6) Sahabat yang telah membantu dan memberikan motivasi dalam menyelesaikan Penyusunan Proposal ini

Semoga bantuan serta budi baik yang telah diberikan kepada peneliti, mendapat balasan dari Tuhan Yang Maha Esa. Besar harapan peneliti agar Sk ripsi ini dapat bermanfaat.

\section{REFERENSI}

I. Kemenkes RI. (2019). Profil Kesehatan Indonesia 2018 [Indonesia Health Profile 2018]. http://www.depkes.go.id/resources/download/pus datin/profil-kesehatan-indonesia/Data-danInformasi_Profil-Kesehatan-Indonesia-2018.pdf

2. KEMENKES 2018. (2018). Laporan Nasional RISKESDAS 2018.pdf. In Badan Penelitian dan Pengembangan Kesehatan (p. 198). http://labdata.litbang.kemkes.go.id/images/downloa d/laporan/RKD/2018/Laporan Nasional RKD20I 8_FINAL.pdf

3. Provinsi, L., \& Tengah, K. (20I8). Riskesdas20/8. https://ejournal2.litbang.

kemkes.go.id/index.php/lpb/article/view/3759

4. Pitters, T. S., Kandou, G. D., Nelwan, J. E., Kesehatan, F., Universitas, M., \& Ratulangi, S. (2019). Dukungan Keluarga Dalam Hubungannya Dengan Kepatuhan Minum Obat Pada Pasien Tuberculosis Paru Di Puskesmas Ranotana Weru. Kesmas, 7(5).

5. Notoatmodjo. S. (20I5). Metode Penelitian Kesehatan. Jakarta: Rineka Cipta.

6. Mongi, T. O., Rottie, J. V, \& Torar, A. (20I7). Hubungan Dukungan Keluarga Dengan Kepatuhan Minum Obat Pasien Tuberculosis Di Ruang Irina C5 Rsup Prof. Dr. Rd Kandou .... Journal Of Community and ..., 5, 16-25. http://ejournal.unpi.ac.id/index.php/JOCE/article/vi $\underline{\mathrm{ew} / 162}$

7. Netty, N., Kasman, K., \& Ayu, S. D. (20/8). Hubungan Peran Petugas Kesehatan Dan Dukungan Keluarga Dengan Tingkat Kepatuhan Minum Obat Pada Penderita Tuberkulosis (Tb) Paru Bta Positif Di Wilayah Kerja Upt. Puskesmas Martapura I. An-Nadaa: Jurnal Kesehatan Masyarakat, $5(\mathrm{I})$. https://doi.org//0.31602/ann.v5il. I 728

8. Nesi, A., Subekti, I., \& Putri, R. M. (2017). 
Hubungan Dukungan dan Pengetahuan Keluarga dengan Tingkat Kepatuhan Berobat Penderita TBC Paru di Puskesmas Maubesi. Nursing News, 2(2), 37I-379.

9. Sara, M. S., \& Suprayitno, E. (2017). Hubungan Dukungan Keluarga terhadap Kepatuhan Minum Obat pada Pasien TB Paru di Puskesmas Umbulharjo Yogyakarta. Unisa Yogyakarta, I(I), II0. http://digilib.unisayogya.ac.id/ 3968/I/NASKAH PUBLIKASI.pdf

10. Wianti, A. (20I7). Hubungan Dukungan Keluarga dengan kepatuhan Minum Obat pada Pasien Tuberculosis Paru di Puskesmas Kaladawa Kabupaten Tegal Tahun 2017. Jurnal Kampus STIKes YBIB Majalengka, VII(I4), I-I4. http://ejournal.stikesypib.ac.id/index.php/JK/article/view/5 7 